\title{
Factors Responsible for Low Inclination towards Entrepreneurship in the Public Sector Institutions of Pakistan
}

\author{
Sana Haider Sumra (Corresponding Author) \\ Department of Management Sciences, The Islamia University of Bahawalpur \\ E-mail: sanasumras@yahoo.com
}

Hina Safarish

Manchester, United Kingdom

Email: hinasafarish_gill@yahoo.com

Sana Suhail

Department of Management Sciences, The Islamia University of Bahawalpur

E-mail: sanasuhailchughtai@yahoo.com

Syed Tauqeer Ahmad

Shaheed Zulfikar Ali Bhutto Institute of Science and Technology,

Street \# 09, Plot \# 67, Sector H-8/4, Islamabad 44000, Pakistan

Tel: +92-345-872-4660 E-mail: tauqeer57@gmail.com

Received: May 28, 2011 Accepted: June 13, $2011 \quad$ DOI: 10.5296/jpag.v1i1.699

\begin{abstract}
Entrepreneurship is of great deal of importance and interest all over the world. For developed countries, this new venture formation results in revitalizing the economy, catalyst of technological innovation and change, means of employment and incubator of market and product innovation. For developing countries, it can be taken as means of job creation, engine for economic progress wealth creation and reducing the social differences. Hence, small business enterprises and entrepreneurship is widely encouraged by the governments who
\end{abstract}


make such policies so as to ensure economic growth and entrepreneurship encouragement. This article presents research on factors which influence the inclination of taking entrepreneurship as a career choice among the business graduates in Pakistan. Entrepreneurship can be taken as means to overcome unemployment and improving social status. This study is conducted from business graduates in the three cities of Pakistan; Islamabad, Lahore and Bahawalpur from HEC recognized institutes which were taken as a sample. The information to be collected on variables ranges from determining simply the presence or absence of a variable to ranking the variables on a given scale depending upon the nature of the variable. Our study is Descriptive and Exploratory nature and Z-test Analysis was carried out in order to unearth the relationship between hypothesized Factors i.e., lack of innovation and creativity, lack of risk tolerance, lack of resources, unsupportive social environment, lack of support from self - employed people, the lack of promotion of self - employment from teachers, lack of entrepreneurship education, low number of self employed parents, lack of required human skills, long working hours and will discuss how these variables affect to the low inclination towards entrepreneurship in business students of Pakistan. The present youth of Pakistan is showing a very low inclination towards entrepreneurship and hence, the trend is declining rather than to augment. There are only a small proportion of current business students which are interested in doing their own business. A vast majority is still planning their career to become employees in organizations.

Keywords: Entrepreneurship, Business graduates, Public Sector Institutions, Administration

\section{Introduction}

There is an increasing trend observed towards entrepreneurship over the last few years. Small business enterprises are a great deal of contribution to the GDP of the country. (Hatten and Ruhland, 1995; Green et al., 1996; Outcalt, 2000; Alstete, 2002; Morrison, 2000; Rohaizat and Fauziah, 2002; Klapper, 2004; Frank et al., 2005; Gurol and Atsan, 2006). According to Global Entrepreneurship Montror (GEM) study (Minniti et al., 2005), there are variations among the countries in terms of quality and frequency of entrepreneurial activities. As compared to higher income countries, middle income countries have more trend and inclination for self employment.

The number of graduates passing out from the institutes is increasing year to year and exceeds from the market demand as the creation of jobs is less than that of the graduates entering the market. Owing to this reason, entrepreneurship and self employment is a major concern for research and investigation. The management students are the most relevant to the field of business, they are taught how to manage and run a business successfully, and they are expected to have a high level understanding of the dynamics of business and consequently should be expected to start their own business after completing their business studies. Government has always paid attention and facilitated the self employed people who are competent and can be resilient in the global market.

Entrepreneurship or doing one's own business has remained one of the biggest occupations and a source of income since the earliest economies and markets emerged on the face of earth. In the primitive and old societies the men who were having various skills like making the 
simple weapons used those skills to ensure their continued livelihood and existence. With the beginning of the Industrial Revolution the range of the products expanded and so did the range of business opportunities for a potential entrepreneur.

Today when at the start of the $21^{\text {st }}$ century the technological and economical progress has probably taken its toll self - employment still remains as a stable and an increasingly attractive occupation for one to engage in. particularly in the likes of increasing unemployment in our country self - employment becomes a more attractive and rewarding career option for our people and particularly for our students.

It is a matter of common observation that despite being highly attractive the aptitude of our students towards entrepreneurship is not very strong. Through now the state of affairs is seemingly changing but still the general inclination towards self - employment remains very low. The relative rates of self - employment in our country remains very low as compared to those of U.S.A and many other developed countries. The same is true for our business students who are pursuing their business and management education at various public and private institutions throughout the country. Being the business student they are the most relevant people to the field of business and are taught how to manage and run a business prosperously. They are expected to have a high level understanding of the dynamics of business and consequently should be expected to start their own business after completing their studies. However, the business students are showing a very low inclination towards entrepreneurship, they are majorly interested and planning their career to become successful employees in organizations. There are various factors are responsible for this low inclination towards self - employment. This study will try to uncover some of the most important factors which are primarily responsible for this low inclination towards entrepreneurship. Our research is conducted through business students of Bahawalpur, Lahore and Islamabad who are studying in various business institutes mainly in The Islamia University of Bahawalpur, Lahore School of Economics and Muhammad Ali Jinnah University, International Islamic University, and SZABIST.

The basic purpose of this research study is to determine the factors which are actually behind the observed low inclination of business students of Pakistan towards Entrepreneurship. The study will be conducted by following a scientific methodology and all the conclusions will be drawn purely on objective basis. As the problem of this research investigation is to find factors behind low inclination towards entrepreneurship so this research study will give us the required information on the basis of which it can be assessed that whether a particular factor is positively related to low inclination towards entrepreneurship or not. The information in various factors hypothesized to be positively related to low inclination towards entrepreneurship will be collected through the well structured instruments. On the basis of information collected on each factor definitive conclusions will be drawn as to the exact nature of relationship between various factors and low inclination towards entrepreneurship. The factors which are found to be positively related to low inclination towards entrepreneurship or self - employment, as substantiated by the collected information, will be serving as Solution to our research problem. 


\section{Statement of Objectives}

To generate the required information by following a scientific methodology that helps in determining which of the hypothesized factors are actually responsible for low inclination towards entrepreneurship in business students of Islamabad. The significance of this research study stems from the important role of entrepreneurship can play in the overall economic and social development. The results of this study will let us know that why the current business students of Islamabad are not much interested and motivated in pursuing a self - employed career.

The findings of this research study will make those areas quite clear to our business students, business people, society, government and university teachers which are demanding some remedial actions so that the business students are encouraged to pursue their careers by establishing and running their own businesses. If proper actions are taken and an overall commitment is gained from everyone to overcome those factors which are serving as barriers to entrepreneurship ( as reflected in the findings of this study) then the time to come may see the business students if this region as successfully self - employed. Eventually, entrepreneurship can be recognized as a highly rewarding and viable career option by the business students of Islamabad.

\section{Literature Review}

The heightened interest in entrepreneurship is can attributed to several factors; new venture activities are seen as catalyst to the economic growth, increased employment, wealth creation and social well being. Moreover, it contributes to the technological, product and services innovation (Mueller and Thomas, 2000; Jack and Anderson, 1999). Entrepreneurship is of critical importance for the developing countries and for the encouragement of such activity, the government develops such policies so as to boost up entrepreneurial activities and self employment to stimulate economic growth. Entrepreneurship is a major concern for research as it is seen as the solution to the problem of unemployment (Kamariah et al. 2004; Salmah 2006). Now a day, markets cannot cater the passing out graduates with immediate employment so, the graduates should carve their own way and change the market conditions by opting self employment. There is a great deal of research work being done on this issue. Different schools of thought have presented different views on this concept. "The 'great person school' views an entrepreneur as a person who is born with an intuitive ability - a sixth sense - and traits such as vigor, energy, persistence and self-esteem. The classical school finds that the central characteristic of entrepreneurial behavior is innovation. The management school describes entrepreneurs as persons who organize, own, manage and assume the risk of an economic venture. The leadership school views entrepreneurs as leaders of people who have the ability to adapt their style to the needs of people. In contrast, the entrepreneurship school posits that entrepreneurial skills can be useful in complex organizations through the development of independent units to create market and expand services". This study focuses on the factors which affect the trend and inclination towards entrepreneurship, these factors can be psychological or monetary. There can be need for achievement, need for wealth, social status, locus of control, risk taking, self confidence, 
need for independence etc (Begley and Boyd, 1987; Brockhaus, Sr. and Horwitz, 1986). A model by Bygrave (1989) shows that need for achievement, internal locus of control, tolerance to ambiguity and propensity to take risk account for attitude towards entrepreneurship. Also, according to Robinson et al. (1991), innovativeness, self confidence, need for achievement and control add to this attitude. Shaver and Scott (1991) added that the most important characteristics in entrepreneurial literature are need for achievement and locus of control.

As a matter of first step in the scientific methodology of our research study a preliminary investigation was conducted to uncover the possible factors serving as barriers to entrepreneurship. MBA students were interviewed to know what they believe is behind low trend towards entrepreneurship. As a result of this preliminary investigation various factors were identified to be serving as barriers to entrepreneurship. The information collected on these variables will range from determining simply the presence or absence of a variable to ranking the variables on a given scale depending upon the nature of the variable. The information thus generated will let us know whether a particular hypothesis is substantiated or not.

\section{Hypothesis}

The various factors with a brief explanation and the associated hypothesis are given below:

\subsection{Innovation and Creativity}

Innovation and creativity are regarded as driving forces towards self-employment or entrepreneurship. Lack of creativity with respect to new products and services in Students is somewhat responsible for low inclination towards self-employment.

$\mathrm{H}_{\mathrm{o}}$ : Lack of innovation and creativity and low inclination towards self-employment are not positively related.

$\mathrm{H}_{\mathrm{A}}$ : Lack of innovation and creativity and low inclination towards self - employment are positively related.

\subsection{High Risk}

Starting your own business means you are taking a fairly high degree of risk taking the form of uncertain income, delayed return etc. That may be a factor towards low level of self-employment.

$\mathrm{H}_{\mathrm{o}}$ : High risk associated with self - employment is not positively related to low inclination towards entrepreneurship.

$\mathrm{H}_{\mathrm{A}}$ : High risk associated with self - employment is positively related to low inclination towards entrepreneurship.

\subsection{Lack Of Resources}

The lack of financial, technical and human resources forces graduates to take-up jobs instead of starting their own business. 
$\mathrm{H}_{\mathrm{o}}$ : Low inclination towards self - employment and lack of resources are not positively related.

$\mathrm{H}_{\mathrm{A}}$ : Low inclination towards self - employment and lack of resources are positively related.

\subsection{Unsupportive Social Environment}

Our culture or social environment does not encourage being self-employed. Normally a person serving at a high post in an organization than small business owners, who are self-employed, is perceived to be better. This is also a factor responsible for low trend towards self-employment.

$\mathrm{H}_{0}$ : Low trend towards self - employment and unsupportive social environment are not positively related.

$\mathrm{H}_{\mathrm{A}}$ : Low trend towards self - employment and unsupportive social environment are positively related.

\subsection{Lack Of Advocacy From Teachers}

The university teachers normally do not regard or promote self-employment as a desirable and viable career path which is responsible for low desire for self-employment.

$\mathrm{H}_{\mathrm{o}}$ : Low inclination towards self - employment is not positively related to the lack of promotion of self-employment from teachers

$\mathrm{H}_{\mathrm{A}}$ : Low inclination towards self - employment is positively related to the lack of promotion of self-employment from teachers

\subsection{Theoretical Emphasis Of University Courses}

The education imparted at university level has a fairly high degree of theoretical emphasis without being much practical. The students normally have a lack of practical exposure.

$\mathrm{H}_{0}$ : Theoretical emphasis of university courses is not positively related to low inclination towards self-employment.

$\mathrm{H}_{\mathrm{A}}$ : Theoretical emphasis of university courses is positively related to low inclination towards self-employment.

\subsection{Lack Of Entrepreneurship Education}

In MBA degree there are only a limited number of entrepreneurship or self-employment courses. In most cases there is only one course of "Entrepreneurship" which is taught, and with its heavy theoretical emphases. It is by no means sufficient to increase the trend towards self-employment. There is a need to increase the number of such courses.

$\mathrm{H}_{\mathrm{o}}$ : Lack of entrepreneurship education is not positively related to low inclination towards self-employment.

$\mathrm{H}_{\mathrm{A}}$ : Lack of entrepreneurship education is positively related to low inclination towards selfemployment. 


\subsection{Low Number Of Self-Employed Parents}

It is more likely that it either father or mother is self-employed or there is a family business then one will join it after completing MBA or other graduation as there is relatively low number of parents who are self-employed so there are less number of students aspiring to be self-employed by continuing their family business.

$\mathrm{H}_{\mathrm{o}}$ : Low number of self - employed parents and low inclination towards self - employment are not positively related.

$\mathrm{H}_{\mathrm{A}}$ : Low number of self - employed parents and low inclination towards self-employment are positively related.

\subsection{Difficulty In Selecting The Right Business}

If a Business Graduate makes a firm decision to start his or her own business the first question that comes to mind is, "Which Business to Start?"

A number of alternatives may be considered and normally it is difficult to select the best one. The aspirant may end up in changing his decision for self - employment due to this situation.

$\mathrm{H}_{\mathrm{o}}$ : Difficulty in selecting the right business for self-employment is not positively related to low inclination towards self-employment.

$\mathrm{H}_{\mathrm{A}}$ : Difficulty in selecting the right business for self - employment is positively related to low inclination towards self-employment.

\subsection{Role Of Government}

The Government is not playing an important role in encouraging self - employment. The Government is not providing the required financial and technical assistance to make self employment a feasible career option.

$\mathrm{H}_{\mathrm{o}}$ : Lack of government support is not positively related to low inclination towards self employment.

$\mathrm{H}_{\mathrm{A}}$ : Lack of government support is positively related to low inclination towards self employment.

\subsection{Previous Unsuccessful Business Experience}

If any student has an unsuccessful experience of doing a business in the past then this may de - motivate him or her to start his or her own business once again.

$\mathrm{H}_{\mathrm{o}}$ : Previous unsuccessful business experience is not positively related to low inclination towards self-employment.

$\mathrm{H}_{\mathrm{A}}$ : Previous unsuccessful business experience is positively related to low inclination towards self-employment.

\subsection{Starting Your Own Business Is Highly Challenging}


Starting your own business poses a great challenge to your perseverance and creativity. Due to this very low number of students are in favor of doing their own business

$\mathrm{H}_{\mathrm{o}}$ : High degree of challenge posed by a business and low inclination towards self employment are not positively related.

$\mathrm{H}_{\mathrm{A}}$ : High degree of challenge posed by a business and low inclination towards self employment are positively related.

\subsection{Obligation Of Directly Responding To Customer Complaints}

When you own a business you have to directly respond to any complaints by the customers. This is particularly true when you are self - employed in a small scale business. You have to handle all the customer complaints yourself effectively failing which you may loose a considerable customer base.

$\mathrm{H}_{\mathrm{o}}$ : Direct responsibility to handle customer complaints and low inclination towards self employment are not positively related.

$\mathrm{H}_{\mathrm{A}}$ : Direct responsibility to handle customer complaints and low inclination towards self employment are positively related.

\subsection{Lack Of Role Models}

It is hard to find and seek guidance from Entrepreneurs who are now successfully running their own business. There are few number of university teachers who are also successful entrepreneurs. Both entrepreneurs and university teachers who are also successfully self employed can serve as role models for current students.

$\mathrm{H}_{\mathrm{o}}$ : Lack of role models (successful entrepreneurs) is not positively related to low inclination towards self-employment.

$\mathrm{H}_{\mathrm{A}}$ : Lack of role models (successful entrepreneurs) is positively related to low inclination towards self-employment.

\subsection{Requirements Of High Human Skills}

Whether you need a small scale or large scale business not only you have to hire some people but also attend to their requirements and keep them happy. This may be perceived as an extra or added responsibility for managing your own business effectively.

$\mathrm{H}_{\mathrm{o}}$ : Requirement of high human skills is not positively related to low inclination towards self - employment.

$\mathrm{H}_{\mathrm{A}}$ : Requirement of high human skills is positively related to low inclination towards selfemployment. 


\subsection{6. $\quad$ Long Working Hours}

Starting your own business means you have to devote a fairly large part of your time to your business. The timings of 9 to 5 may not be followed and you may be required to work even on Sundays. This is particularly true when your business in its startup. The family and social commitments may take a back seat and this may cause some disruption in your family life.

$\mathrm{H}_{\mathrm{o}}$ : Long working hours / extra commitment demanded by your own business is not positively related to low inclination towards self-employment.

$\mathrm{H}_{\mathrm{A}}$ : Long working hours / extra commitment demanded by your own business is positively related to low inclination towards self-employment.

\subsection{Lack Of Support From Self - Employed People}

Persons who are already self - Employed do not give much advice or extend a helping hand to those who are looking to start their own business.

$\mathrm{H}_{\mathrm{o}}$ : Lack of support from self - employed people and low inclination towards self employment are not positively related.

$\mathrm{H}_{\mathrm{A}}$ : Lack of support from self - employed people and low inclination towards self employment are positively related.

\subsection{Geographic Disadvantage for the Graduates}

The Business Graduates may not find as much business opportunities for self - employment as are open to graduates of big cities like Lahore and Karachi. This may be a factor resulting in low relative self - employment in Islamabad.

$\mathrm{H}_{\mathrm{o}}$ : Small relative self - employment opportunities are not positively related to low inclination towards self-employment

$\mathrm{H}_{\mathrm{A}}$ : Small relative self - employment opportunities are positively related to low inclination towards self-employment.

\section{Methodology and Research Design}

This study is Quantitative and Exploratory. We are conducting a research study aimed at finding the factors responsible for low inclination towards entrepreneurship in the business students of Bahawalpur, Lahore and Islamabad. Survey technique is used in the research. A formal questionnaire will be designed and used for the collection of data. The questionnaire will be designed is such a way that it is easy to understand for respondent and also some general and relax questions are also including in it. The different types of scales are used in this research like dichotomous scale, Likert scale, itemized balanced rating scale and itemized unbalanced rating scale. Most likely it also covers all the factors under investigation. 


\section{Macrothink}

\section{Calculating Sampling Size (n)}

\section{Formula}

The sampling size (e) is calculated by using this formula:

$\mathrm{n}=\quad \underline{\mathrm{Z}^{2} \mathrm{pq}}$

Where;

$\mathrm{n}=$ sampling size

$Z=$ level of confidence $=95 \%$

$\mathrm{P}=$ proportion of students who do not want to be self - employed

$\mathrm{Q}=1-\mathrm{p}$

Beta $=$ allowable error $= \pm 5 \%$ 
Theoretical Framework

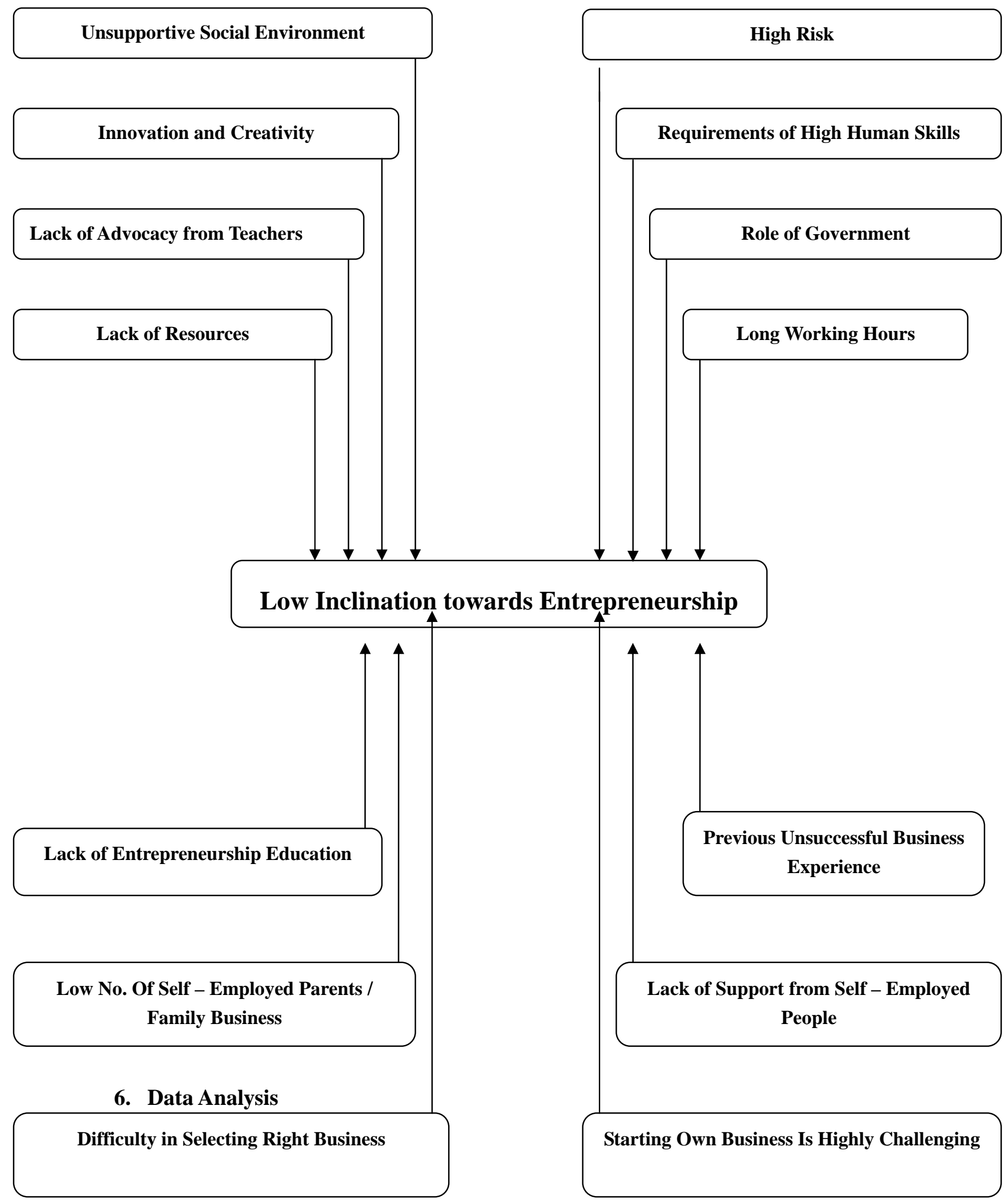




\section{Data Analysis}

\subsection{Lack of Innovation and Creativity}

Innovation and creativity are regarded as driving forces towards self-employment or entrepreneurship. Lack of creativity with respect to new products and services in Students is somewhat responsible for low inclination towards self-employment.

\section{Hypothesis}

$\mathrm{H}_{\mathrm{o}}$ : Lack of innovation and creativity and low inclination towards self-employment are not related.

$\mathrm{H}_{\mathrm{A}}$ : Lack of innovation and creativity and low inclination towards self - employment are positively related.

Question

Have you ever invented, designed or thought of a new product or service that you think will have a commercial market if launched?

\section{No}

Yes

Specify

Frequency Distribution

Invented or Thought Of a New Product

\begin{tabular}{|l|l|l|l|l|l|}
\hline Frequency & Percent & Yes & $\%$ & No & $\%$ \\
\hline 100 & $100 \%$ & 10 & $10 \%$ & 90 & $90 \%$ \\
\hline
\end{tabular}

The question was asked to gauge the creativity and innovation of the respondents which is every important for the entrepreneur to start and continue his/her business. Only ten of our respondents out of hundred have invented or thought of new product or service which have

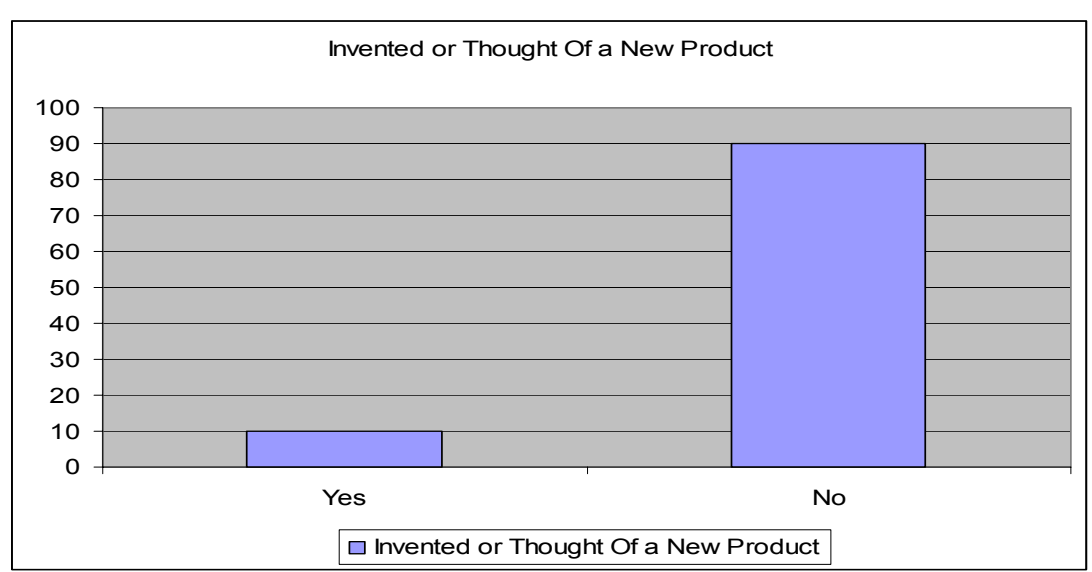
commercial market if launched and our ninety respondents [90\%] haven't invented, designed or thought of any product which have commercial market if launched. 
Null hypothesis $\quad \mathrm{P}=0$

Alternative hypothesis $\quad \mathrm{P} \# 0$

Where "P" represent population proportion.

Level of Confidence

$1-\mathrm{A}=95 \% \quad, \quad \alpha=5 \%$ or .05

Test Statistic

$\mathrm{Z}=$

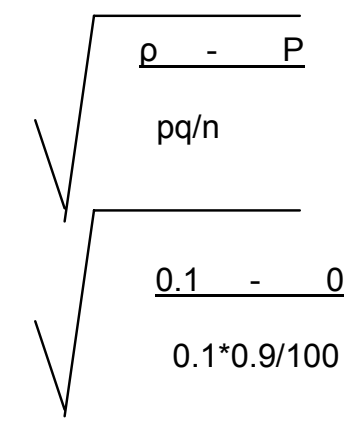

$\rho$ shows sample proportion.

$$
\begin{aligned}
& Z=\frac{0.1}{0.03} \\
& Z=3.33
\end{aligned}
$$

Critical Value

$Z \alpha / 2= \pm 1.645 \quad, \quad Z \alpha / 2=+1.645 \quad$ or $\quad-1.645$

\section{Critical Region}

$Z \alpha / 2>+1.645 \quad$ or $\quad Z \alpha / 2<-1.645$

From the above analysis we got $Z=3.33$ while our critical region is 1.645 . It means we reject our null hypothesis and accept our alternative hypothesis which shows that Lack of innovation and creativity and low inclination towards self - employment are positively related. As out of 100 respondents 90 responses in favor of our above statement which reflect strong relationship between lack of innovation and low creativity and low inclination towards self - employment.

\subsection{Lack of Risk Tolerance}

Starting your own business means you are taking a fairly high degree of risk taking the form of uncertain income, delayed return etc. It is found that people and students of Islamabad have minimum risk tolerance. That may be a factor towards low level of self-employment. 
$\mathrm{H}_{\mathrm{o}}$ : Lack of risk tolerance in the business students is not related to low inclination towards entrepreneurship.

$\mathrm{H}_{\mathrm{A}}$ : Lack of risk tolerance in the business students is positively related to low inclination towards entrepreneurship.

Question

Rank the following risks with respect to their weightage for you, if you do your own business after MBA? [Rank 1 for the risk of most weightage and so on].

Delayed Returns

Uncertain Income

Chances of Failure

Frequency Distribution

Weightage of the Risks

\begin{tabular}{|l|l|l|l|l|l|l|l|}
\hline Frequency & Percent & $\begin{array}{l}\text { Delayed } \\
\text { Returns }\end{array}$ & $\%$ & $\begin{array}{l}\text { Uncertain } \\
\text { Income }\end{array}$ & $\%$ & $\begin{array}{l}\text { Chances } \\
\text { of } \\
\text { Failure }\end{array}$ & $\%$ \\
\hline 100 & $100 \%$ & 20 & $20 \%$ & 30 & $30 \%$ & 50 & $50 \%$ \\
\hline
\end{tabular}

The question was asked about the weight age of the certain risks if the respondent starts his/her own business after completing his/her MBA. Our twenty respondents had said that for them delayed returns are the most resisting risk towards entrepreneurship. Thirty respondents said that for them uncertain income is most resisting risk towards entrepreneurship and remaining fifty had said that for them chances of failure is most resisting risk which resists

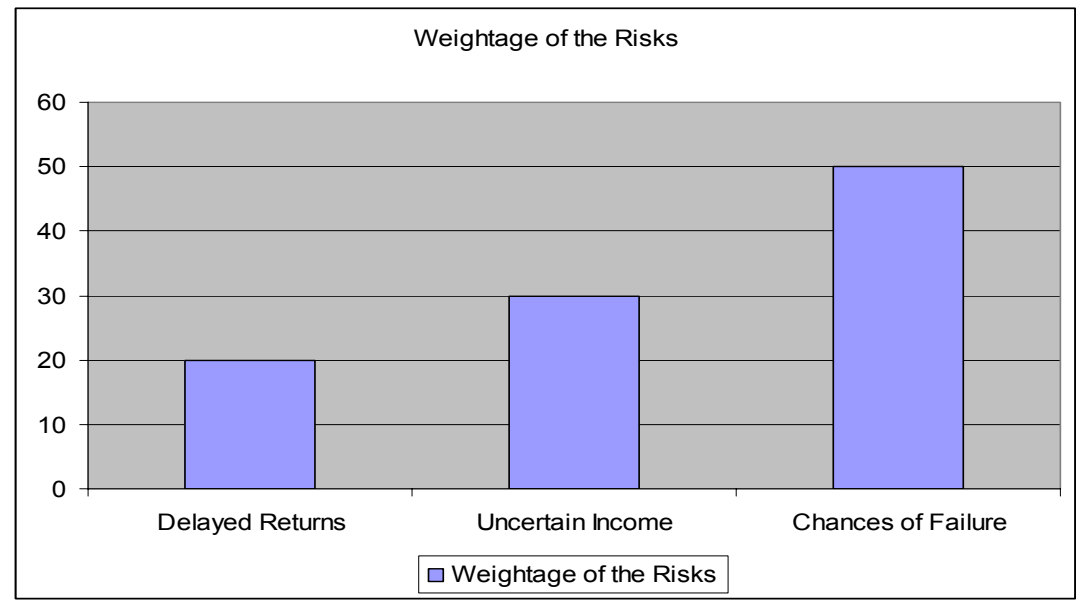
them to start their own business after completing their MBA. 
Hypothesis

Null hypothesis $\quad \mathrm{P}=0$

Alternative hypothesis $\mathrm{P} \# 0$

Where "P" represent population proportion.

\section{Level of Confidence}

$1-A=95 \% \quad, \quad \alpha=5 \%$ or .05

Test Statistic

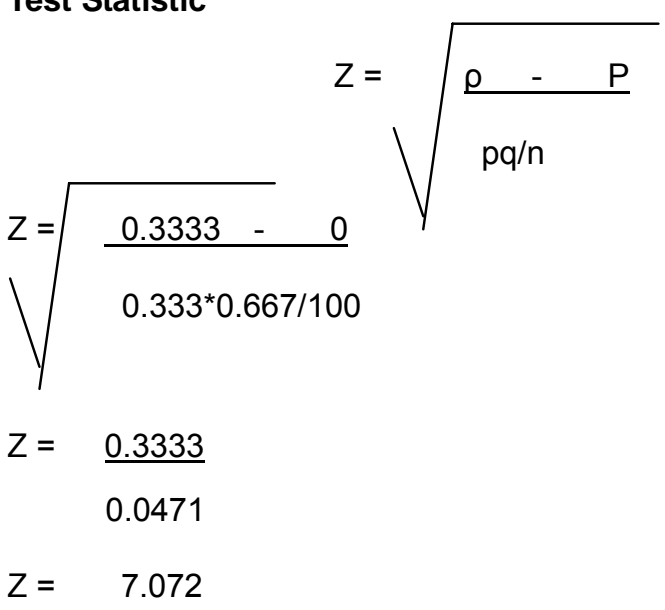

$\rho$ shows average of sample proportions.

Critical Value

$\mathrm{Z} \alpha / 2= \pm 1.645 \quad, \quad \mathrm{Z} \alpha / 2=+1.645 \quad$ or $\quad-1.645$

\section{Critical Region}

$\mathrm{Z} \alpha / 2>+1.645 \quad$ or $\quad \mathrm{Z} \alpha / 2<-1.645$

From the above analysis we got $Z=7.072$ while our critical region is 1.645 . It means we reject our null hypothesis and accept our alternative hypothesis which shows that Lack of risk tolerance in the business students is positively related to low inclination towards entrepreneurship. This reflects strong relationship between risk tolerance in business students and low inclination towards entrepreneurship.

\subsection{Lack of Resources}

The lack of financial, technical and human resources forces graduates to take-up jobs instead of starting their own business.

Hypothesis

$\mathrm{H}_{\mathrm{o}}$ : Low inclination towards self-employment and lack of resources are not related.

$\mathrm{H}_{\mathrm{A}}$ : Low inclination towards self-employment and lack of resources are positively related.

Question 
Rank the following resources with respect to their importance for you for starting your business after MBA? [Rank 1 for the most important resources and so on].

Financial Resources

Human Resources

Technical Resources

Business Experience

Frequency distribution

Importance of the Resources for Starting the Business

\begin{tabular}{|l|l|l|}
\hline Resources & $\begin{array}{l}\text { Importance } \\
\text { Resources }\end{array}$ & $\begin{array}{l}\text { Cumulative } \\
\text { Percentage }\end{array}$ \\
\hline Financial Resources & 50 & $50 \%$ \\
\hline Human Resources & 15 & $15 \%$ \\
\hline Technical Resources & 10 & $10 \%$ \\
\hline Business Experience & 25 & $25 \%$ \\
\hline
\end{tabular}

The question was asked to know the importance of the various resources for the respondents to start his/her own business after completing the MBA. Our fifty respondents which are accounting for $50 \%$ said that financial resources are most important to start the business. Fifteen respondents which are accounted for $15 \%$ said that human resources are most important to start the business. Ten said that technical resources are most important to start

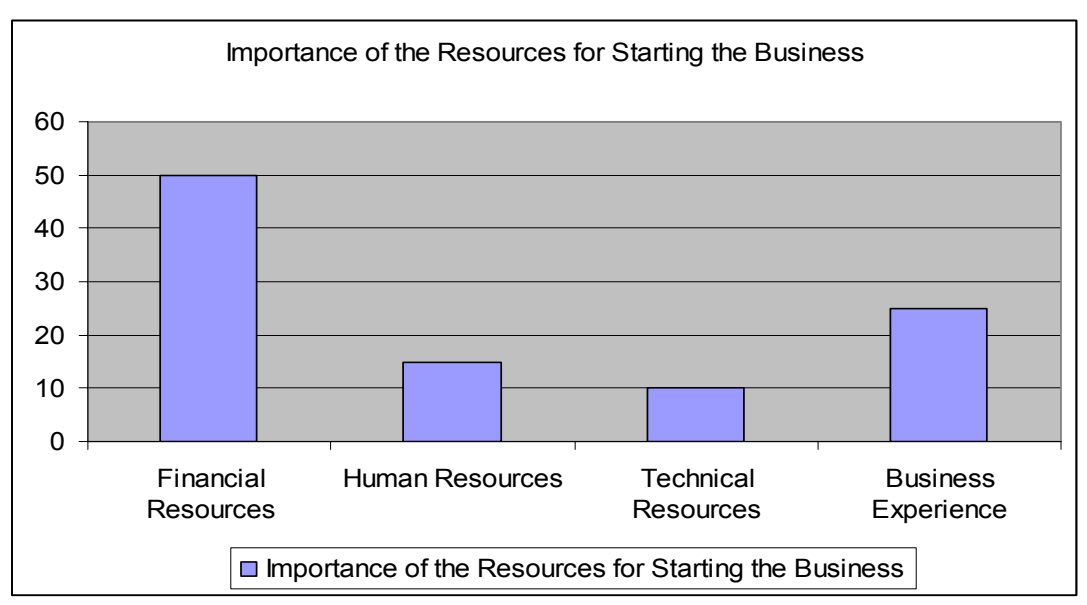

the business and remaining twenty five which are accounting for $25 \%$ said that business experience is the most important for starting once business. 
Hypothesis

Null hypothesis $\quad \mathrm{P}=0$

Alternative hypothesis $\quad \mathrm{P} \# 0$

Where "P" represent population proportion.

Level of Confidence
$1-\mathrm{A}=95 \%$
$\alpha=5 \%$ or .05

Test Statistic

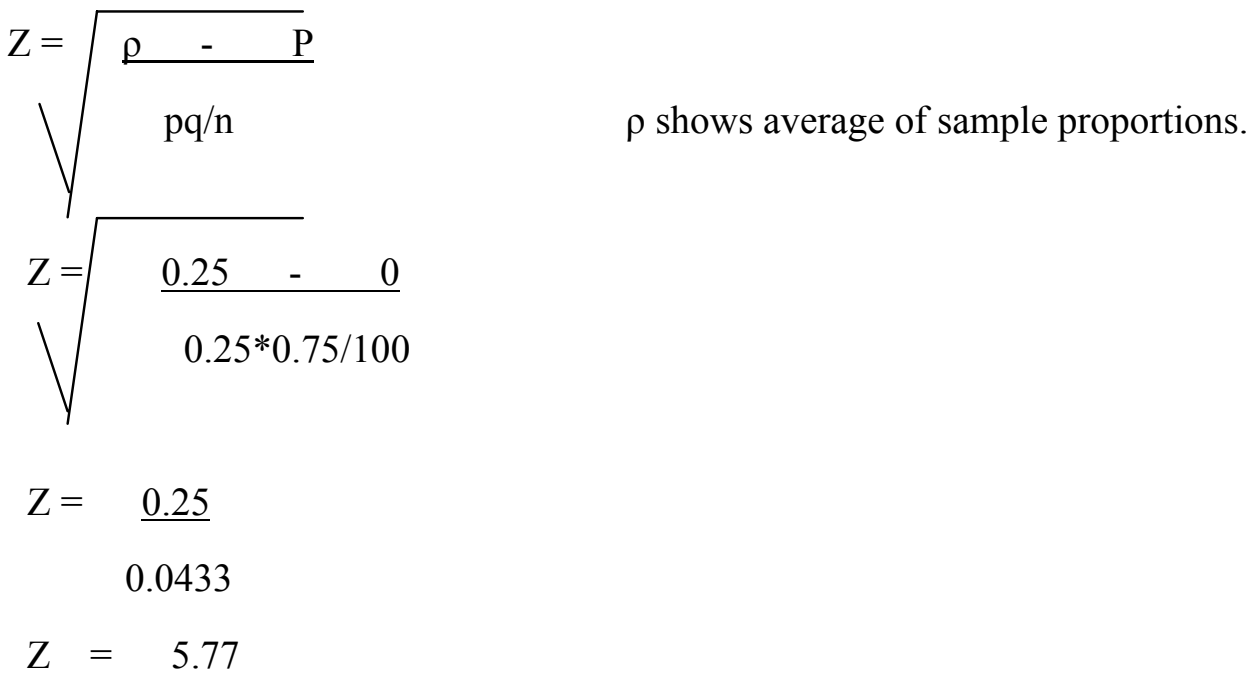

Critical Value

$\mathrm{Z} \alpha / 2= \pm 1.645 \quad, \quad \mathrm{Z} \alpha / 2=+1.645 \quad$ or $\quad-1.645$

Critical Region

$\mathrm{Z} \alpha / 2>+1.645 \quad$ or $\quad \mathrm{Z} \alpha / 2<-1.645$

From the above analysis we got $\underline{Z}=5.77$ while our critical region is 1.645 . It means we reject our null hypothesis and accept our alternative hypothesis which shows that Low inclination towards self - employment and lack of resources are positively related. This reflects strong relationship between lack of resource and Low inclination towards self - employment.

\subsection{Lack of Support from Self-Employed People}

Persons who are already Self - Employed do not give much advice or extend a helping hand to those who are looking to start their own business.

Hypothesis

$\mathrm{H}_{\mathrm{o}}$ : Lack of support from self - employed people and low inclination towards self employment are not related.

$\mathrm{H}_{\mathrm{A}}$ : Lack of support from self - employed people and low inclination towards self - 
employment are positively related.

Question

How would you rate the following sources in terms of their support for self-employment? [Encircle an Appropriate "+" if they support or a "-"if they do not support].

$\begin{array}{lll}+3 & +3 & +3 \\ +2 & +2 & +2 \\ +1 & +1 & +1\end{array}$

Government Support Social Support Support from Self-Employed

People

$\begin{array}{lll}-1 & -1 & -1 \\ -2 & -2 & -2 \\ -3 & -3 & -3\end{array}$

Frequency Distribution

Support for Self - Employment

\begin{tabular}{|l|l|l|l|l|l|l|}
\hline Scale & Govt. Support & $\%$ & Social Support & $\%$ & Support from Entrepreneurs & $\%$ \\
\hline+3 & 20 & $20 \%$ & 45 & $45 \%$ & 15 & $15 \%$ \\
\hline+2 & 20 & $20 \%$ & 25 & $25 \%$ & 40 & $40 \%$ \\
\hline+1 & 30 & $30 \%$ & 10 & $10 \%$ & 20 & $20 \%$ \\
\hline-1 & 20 & $20 \%$ & 15 & $15 \%$ & 5 & $5 \%$ \\
\hline-2 & --- & --- & 5 & $5 \%$ & --- & --- \\
\hline-3 & 10 & $10 \%$ & --- & --- & 20 & $20 \%$ \\
\hline
\end{tabular}

For the start of own business there is necessary that there should be the support from the government, there should be social support and also support from the self - employed people is required for gaining experience and information. We had got very mixed response from that question. All the responses of the respondents are shown in the above table.

Hypothesis

Null hypothesis $\quad \mathrm{P}=0$ 
Alternative hypothesis $\mathrm{P} \# 0$

Where "P" represent population proportion.

Level of Confidence

$$
1-\mathrm{A}=95 \% \quad, \quad \alpha \quad=5 \% \text { or } .05
$$

Test Statistic

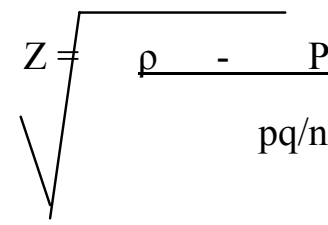

$\rho$ shows average of sample proportions.

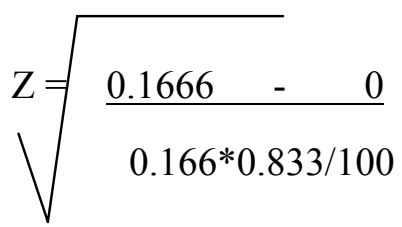

$$
Z=4.472
$$

Critical Value

$\mathrm{Z} \alpha / 2= \pm 1.645 \quad, \quad \mathrm{Z} \alpha / 2=+1.645 \quad$ or $\quad-1.645$

Critical Region

$\mathrm{Z} \alpha / 2>+1.645$

$$
\text { or } \quad Z \alpha / 2<-1.645
$$

From the above analysis we got $\underline{Z=4.472}$ while our critical region is 1.645 . It means we reject our null hypothesis and accept our alternative hypothesis which shows that Lack of social support and low inclination towards self - employment are positively related. This reflects strong relationship between Lack of social support and Low inclination towards self employment.

\subsection{Lack of Advocacy from Teachers}

The university teachers normally do not regard or promote self-employment as a desirable and viable career path which is responsible for low desire for self-employment.

Hypothesis

$\mathrm{H}_{\mathrm{o}}$ : Low inclination towards self-employment is not related to the lack of promotion of self - employment from teachers

$\mathrm{H}_{\mathrm{A}}$ : Low inclination towards self - employment is positively related to the lack of promotion of self-employment from teachers 
Question

Have you ever heard your university teachers saying a following type of sentence for their students? [Encircle Appropriate Number].

"Doing your own business after MBA is a Superior and Viable career option for You"

Hardly Heard Casually Heard Often Heard Frequently

Heard

Frequency Distribution

Doing Your Own Business After MBA Is A Superior And Viable Career Option For You.

\begin{tabular}{|l|l|l|}
\hline Scale & Doing Business is Superior and Viable & Percentage \\
\hline Hardly Heard & 50 & $50 \%$ \\
\hline Casually Heard & 30 & $30 \%$ \\
\hline Often Heard & 15 & $15 \%$ \\
\hline Frequently Heard & 5 & $5 \%$ \\
\hline
\end{tabular}

For encouraging towards entrepreneurship there is also a role of the teachers to motivate their students to start their own business after completing MBA. But university teachers are not motivating them towards the self - employment which can be analyzed from the responses of the above table.

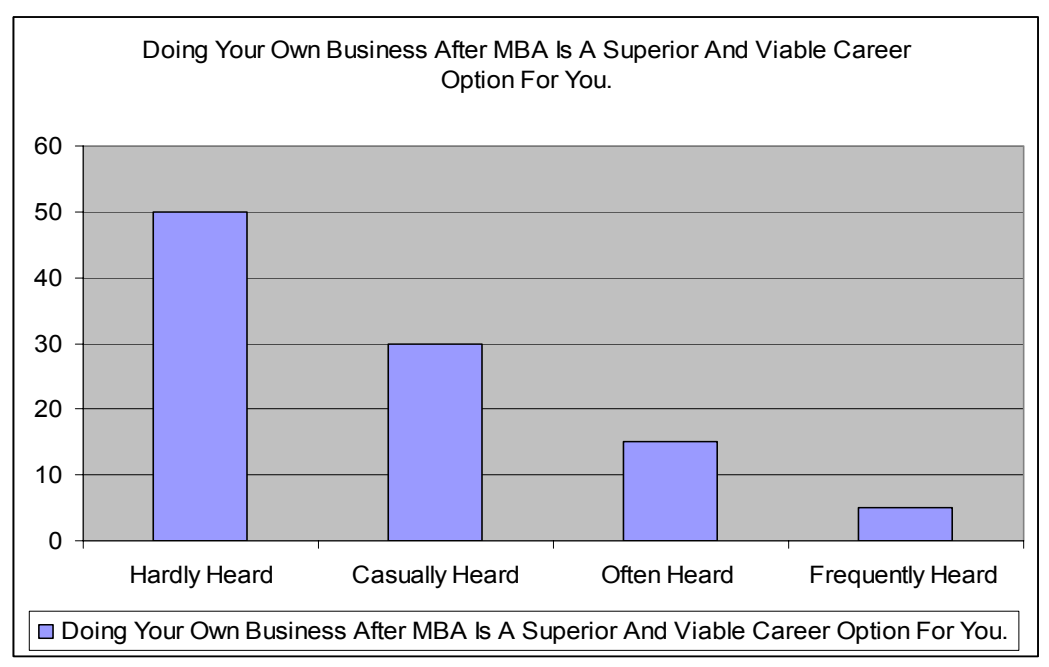


Hypothesis:

Null hypothesis $\quad \mathrm{P}=0$

Alternative hypothesis $\mathrm{P} \# 0$

Where "P" represent population proportion.

Level of Confidence

$1-\mathrm{A}=95 \% \quad, \quad \alpha=5 \%$ or .05

Test Statistic

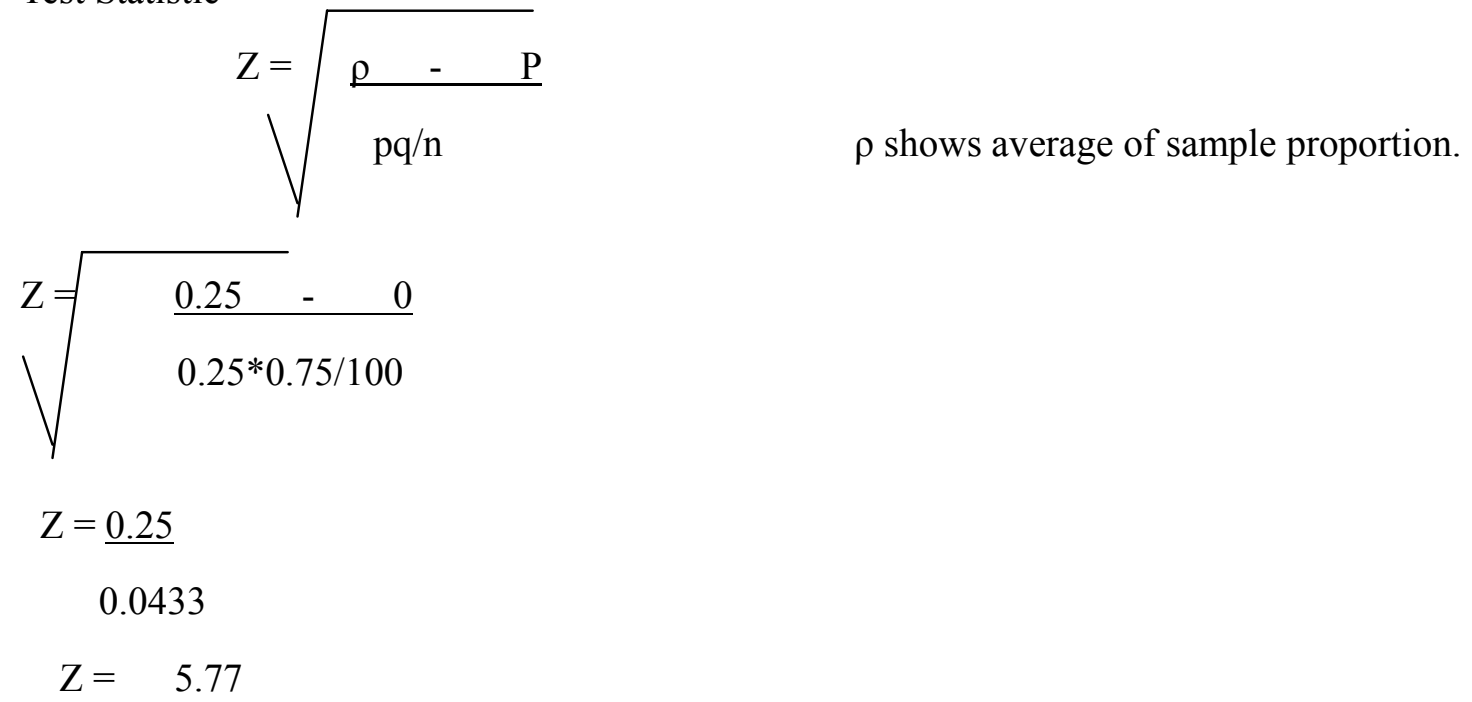

Critical Value

$\mathrm{Z} \alpha / 2= \pm 1.645 \quad, \quad \mathrm{Z} \alpha / 2=+1.645 \quad$ or $\quad-1.645$

Critical Region

$\mathrm{Z} \alpha / 2>+1.645 \quad$ or $\quad \mathrm{Z} \alpha / 2<-1.645$

From the above analysis we got $\underline{Z}=5.77$ while our critical region is 1.645 . It means we reject our null hypothesis and accept our alternative hypothesis which shows that Low inclination towards self - employment is positively related to the lack of promotion of self employment from teacher which reflect strong relationship between lack of promotion of self - employment from teacher and Low inclination towards self - employment

\subsection{Lack of Entrepreneurial Education}

In MBA degree there are only a limited number of entrepreneurship or self-employment courses. In most cases there is only one course of "Entrepreneurship" which is taught, and with its heavy theoretical emphases. It is by no means sufficient to increase the trend towards self-employment. There is a need to increase the number of such courses. 
Hypothesis

$\mathrm{H}_{\mathrm{o}}$ : Lack of entrepreneurship education is not related to low inclination towards self employment.

$\mathrm{H}_{\mathrm{A}}$ : Lack of entrepreneurship education is positively related to low inclination towards selfemployment.

Question

Indicate the degree to which you agree or disagree with the following statements by writing appropriate number in the given space.

There is a severe lack of education and training related to self-employment in course structure of MBA.

StronglyDisagree Neither Disagree Agree Strongly Agree Disagree

Nor Agree

$\begin{array}{lllll}1 & 2 & 3 & 4 & 5\end{array}$

Frequency Distribution

Lack Of Education And Training Related To Self-Employment In Course Structure Of MBA.

\begin{tabular}{|l|l|l|}
\hline Scale & Lack of Education and Training & Percentage \\
\hline Strongly Disagree & ---- & ---- \\
\hline Disagree & 5 & $5 \%$ \\
\hline $\begin{array}{l}\text { Neither Disagree Nor } \\
\text { Agree }\end{array}$ & 5 & $5 \%$ \\
\hline Agree & 55 & $55 \%$ \\
\hline Strongly Agree & 35 & $35 \%$ \\
\hline
\end{tabular}

There is need for the training and education which is related to the self - employment in the course structure of MBA. 5\% of our respondents said that MBA course structure providing them education and training for the self - employment. 55\% said agree that there is no education and training for the self - employment and 35\% are strongly agree that there is no education and training for the self - employment. 


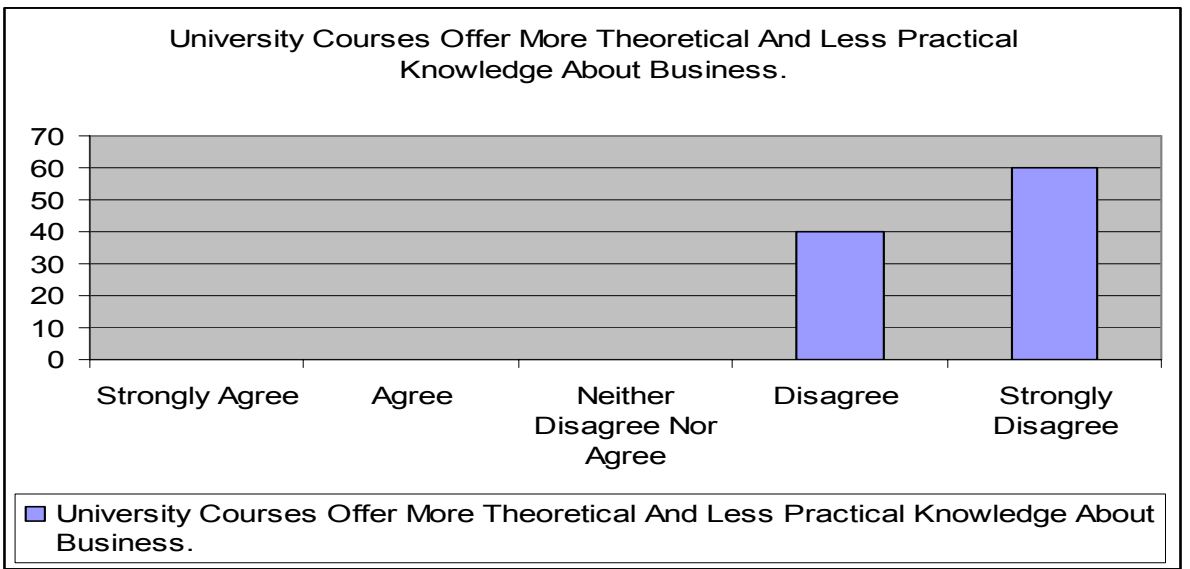

Hypothesis

Null hypothesis $\quad \mathrm{P}=0$

Alternative hypothesis $\mathrm{P} \# 0$

Where "P" represent population proportion.

Level of Confidence

$1-\mathrm{A}=95 \% \quad, \quad \alpha=5 \%$ or .05

Test Statistic

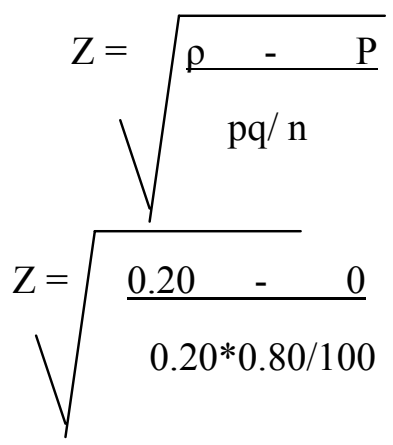

$\rho$ shows average of sample proportions.

$\mathrm{Z}=\underline{0.20}$

0.04

$\mathrm{Z}=5.0$

Critical Value

$\mathrm{Z} \alpha / 2= \pm 1.645 \quad, \quad \mathrm{Z} \alpha / 2=+1.645 \quad$ or $\quad-1.645$

Critical Region

$\mathrm{Z} \alpha / 2>+1.645 \quad$ or $\quad \mathrm{Z} \alpha / 2<-1.645$

From the above analysis we got $Z=5.0$ while our critical region is 1.645 . It means we reject 
our null hypothesis and accept our alternative hypothesis which shows that Lack of entrepreneurship education is positively related to low inclination towards self - employment which reflect strong relationship between Lack of entrepreneurship education and low inclination towards self - employment.

\subsection{Low Number of Self-Employed Parents}

It is more likely that it either father or mother is self-employed or there is a family business then one will join it after completing MBA or other graduation. As there is relatively low number of parents who are self-employed so there are less number of students aspiring to be self-employed by continuing their family business.

Hypothesis

$\mathrm{H}_{\mathrm{o}}$ : Low number of self - employed parents and low inclination towards self - employment are not related.

$\mathrm{H}_{\mathrm{A}}$ : Low number of self - employed parents and low inclination towards self-employment are positively related.

Question

Is any of your parents (either father or mother) Self - Employed?

Yes No

Frequency Distribution

Parents Self - Employed or Not Self - Employed

\begin{tabular}{|l|l|l|l|l|l|}
\hline Frequency & Percent & $\begin{array}{l}\text { Self-Employed } \\
\text { Parents }\end{array}$ & $\begin{array}{l}\text { \%age of Self }- \\
\text { Employed }\end{array}$ & $\begin{array}{l}\text { Not Self }- \\
\text { Employed } \\
\text { Parents }\end{array}$ & $\begin{array}{l}\text { \%age of } \\
\text { Not Self - } \\
\text { Employed }\end{array}$ \\
\hline 100 & $100 \%$ & 35 & $35 \%$ & 65 & $65 \%$ \\
\hline
\end{tabular}

Business graduates also take encouragement from their parents if they are already doing any business. 35\% of our respondent's parents (either father or mother) is doing own business and only $65 \%$ of the respondent's parents (either father or mother) do not doing their business. 


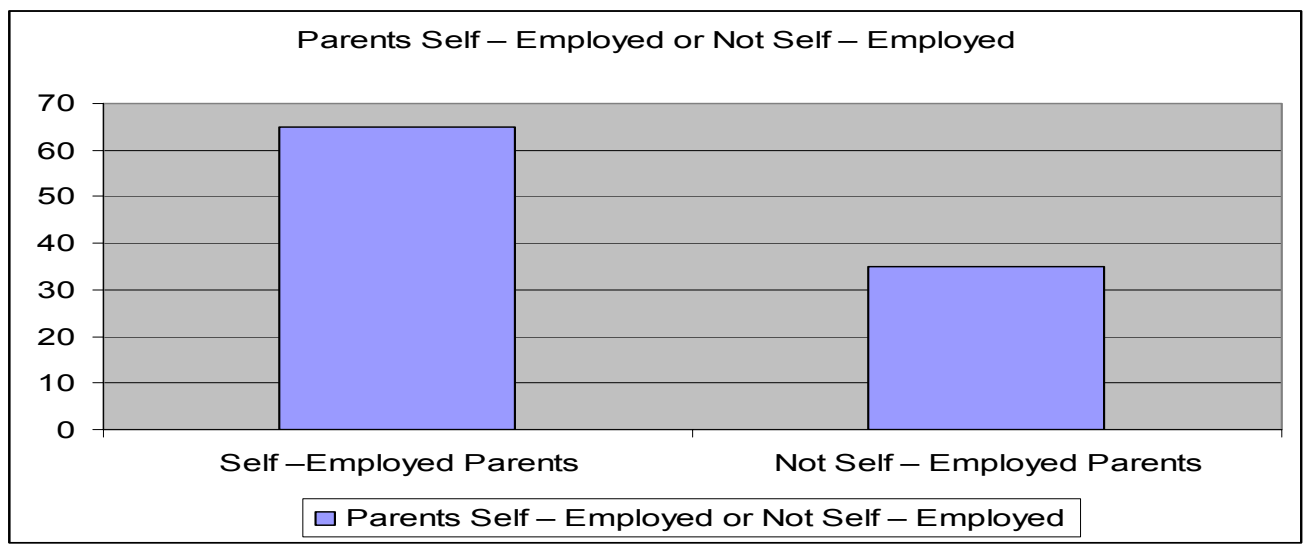

Hypothesis

Null hypothesis $\quad \mathrm{P}=0$

Alternative hypothesis $\mathrm{P} \# 0$

Where "P" represent population proportion.

Level of Confidence
$1-\mathrm{A}=95 \%$
$\alpha \quad=5 \%$ or .05

Test Statistics

$\mathrm{Z}=$

$\sqrt{\rho-p q / n}$

$\rho$ shows sample proportion.

$Z=\sqrt{\frac{0.65-}{0.65 * 0.35 / 100}}$

$Z=\underline{0.65}$

0.0476

$Z=13.63$

Critical Value

$\mathrm{Z} \alpha / 2= \pm 1.645 \quad, \quad \mathrm{Z} \alpha / 2=+1.645 \quad$ or $\quad-1.645$

Critical Region

$\mathrm{Z} \alpha / 2>+1.645 \quad$ or $\quad \mathrm{Z} \alpha / 2<-1.645$

From the above analysis we got $\underline{Z=13.63}$ while our critical region is 1.645 . It means we 
reject our null hypothesis and accept our alternative hypothesis which shows that Low number of self - employed parents and low inclination towards self - employment are positively related. As out of 100 respondents 65 responses in favor of our above statement which reflect strong relationship between Low number of self - employed parents and low inclination towards self - employment

\subsection{Lack of Required Human Skills}

Whether you need a small scale or large scale business not only you have to hire some people but also attend to their requirements and keep them happy. This may be perceived as an extra or added responsibility for managing your own business effectively.

$\mathrm{H}_{\mathrm{o}}$ : Lack of required human skills is not related to low inclination towards self employment.

$\mathrm{H}_{\mathrm{A}}$ : Lack of required human skills is positively related to low inclination towards self employment.

\section{Question}

In acting upon your decision for self-employment how resisting the following "Additional Responsibilities" of managing a business will be? [Encircle Appropriate Number].

Responsibility of Keeping Your

Employees Happy $\quad \begin{array}{llll}1 & 2 & 3 & 4\end{array}$

Not Resisting at All Slightly Resisting $\quad$ Resisting $\quad$ High Resisting

\section{Frequency Distribution}

Responsibility of Keeping Your Employees Happy is Resisting or Not

\begin{tabular}{|l|l|l|}
\hline Scale & $\begin{array}{l}\text { Responsibility of Keeping Your } \\
\text { Employees Happy }\end{array}$ & Percentage \\
\hline Not Resisting at All & 5 & $5 \%$ \\
\hline Slightly Resisting & 25 & $20 \%$ \\
\hline Resisting & 45 & $45 \%$ \\
\hline High Resisting & 30 & $30 \%$ \\
\hline
\end{tabular}




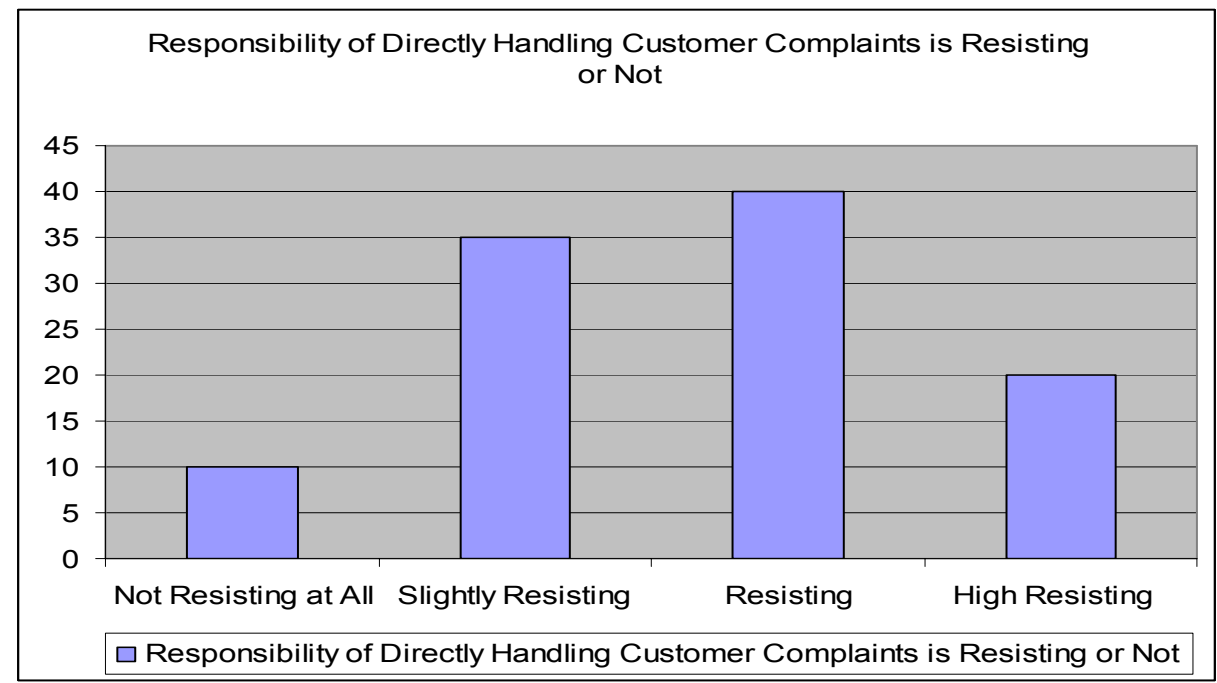

Hypothesis

Null hypothesis $\quad \mathrm{P}=0$

Alternative hypothesis $\quad \mathrm{P} \# 0$

Where "P" represent population proportion.

Level of Confidence
$1-\mathrm{A}=95 \%$
$\alpha=5 \%$ or .05

Test Statistics

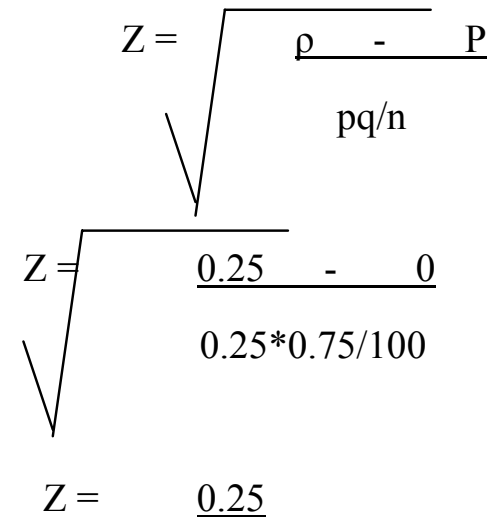

$\rho$ shows average of sample proportions.

0.0433

$$
Z=5.77
$$

Critical Value

$\mathrm{Z} \alpha / 2= \pm 1.645 \quad, \quad \mathrm{Z} \alpha / 2=+1.645 \quad$ or $\quad-1.645$ 
Critical Region

$\mathrm{Z} \alpha / 2>+1.645$

or

$\mathrm{Z} \alpha / 2<-1.645$

From the above analysis we got $\underline{Z}=5.77$ while our critical region is 1.645 . It means we reject our null hypothesis and accept our alternative hypothesis which shows that Lack of required human skills is positively related to low inclination towards self - employment which reflect strong relationship between Lack of required human skills is positively related to low inclination towards self - employment

\subsection{Long Working Hours}

Starting your own business means you have to devote a fairly large part of your time to your business. The timings of 9 to 5 may not be followed and you may be required to work even on Sundays. This is particularly true when your business in its startup. The family and social commitments may take a back seat and this may cause some disruption in your family life.

Hypothesis

$\mathrm{H}_{\mathrm{o}}$ : Long working hours / extra commitment demanded by your own business is not related to low inclination towards self-employment.

$\mathrm{H}_{\mathrm{A}}$ : Long working hours / extra commitment demanded by your own business is positively related to low inclination towards self-employment.

\section{Question}

How much hindrance do you think doing your own business will create in your personal and social life? [Encircle Appropriate Number].

No Hindrance at All

1
Some Hindrance

2
Hindrance

3
High Hindrance

4

Frequency Distribution

Doing Your Own Business Will Create Hindrance in Your Personal and Social Life

\begin{tabular}{|l|l|l|}
\hline Scale & Doing Business creates Hindrance & Percentage \\
\hline No Hindrance at All & 10 & $10 \%$ \\
\hline Some Hindrance & 65 & $65 \%$ \\
\hline Hindrance & 20 & $20 \%$ \\
\hline High Hindrance & 5 & $5 \%$ \\
\hline
\end{tabular}




\section{Macrothink}

Doing your own business will create hindrance in your personal and social life. Of the total 100 respondents, $10 \%$ responded that own business will create no hindrance in the personal and social life. $65 \%$ of the respondents were of the view that owns business will creates some hindrance in the personal and social life. $20 \%$ responded that own business will create hindrance in their personal and social life. $5 \%$ of the respondents were of the view that own business will creates high hindrance in their personal and social life.

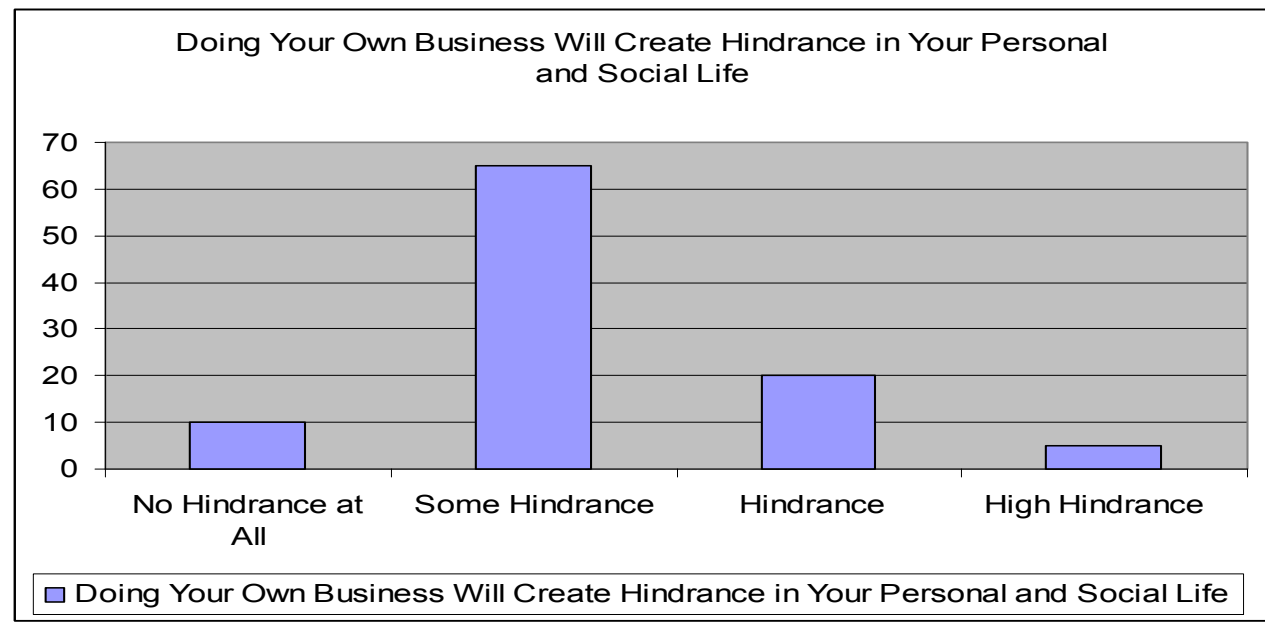

Hypothesis:

Null hypothesis $\quad \mathrm{P}=0$

Alternative hypothesis $\mathrm{P} \# 0$

Where "P" represent population proportion.

Level of Confidence

$1-\mathrm{A}=95 \% \quad, \quad \alpha=5 \%$ or .05

Test Statistics

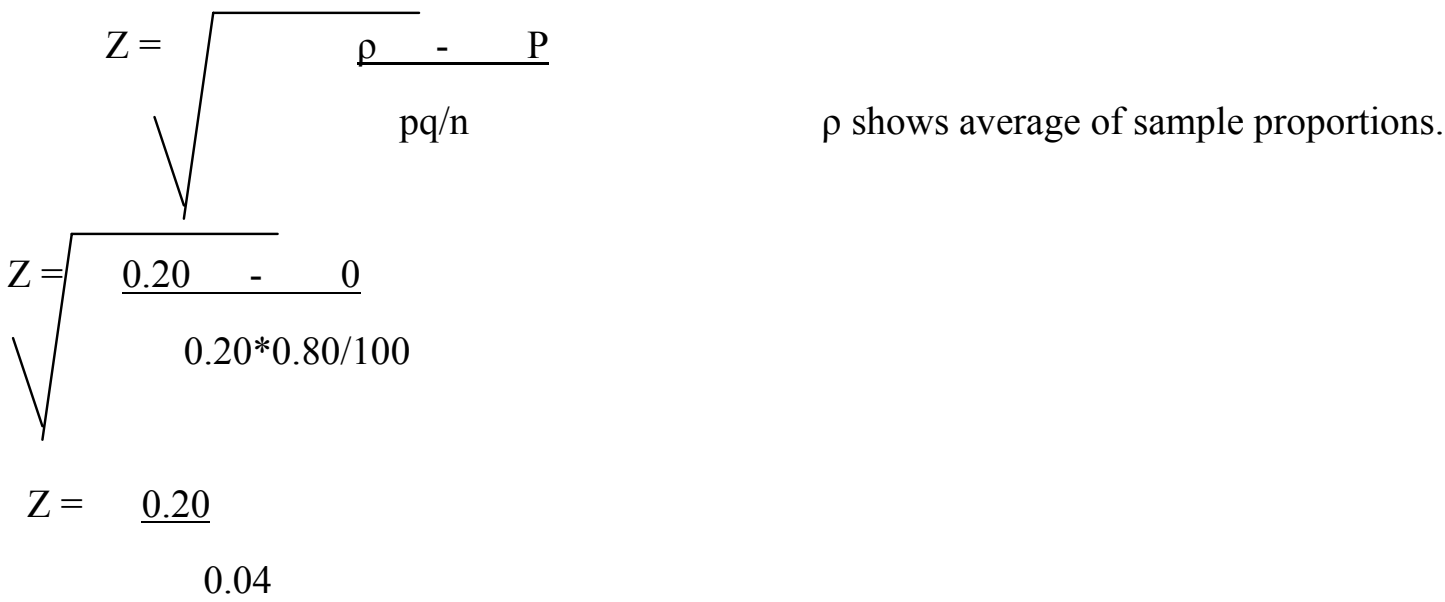

$\mathrm{Z}=5.0$ 
Critical Value

$$
\mathrm{Z} \alpha / 2= \pm 1.645 \quad, \quad \mathrm{Z} \alpha / 2=+1.645 \quad \text { or } \quad-1.645
$$

Critical Region

$\mathrm{Z} \alpha / 2>+1.645 \quad$ or $\quad \mathrm{Z} \alpha / 2<-1.645$

From the above analysis we got $\underline{Z}=5.0$ while our critical region is 1.645 . It means we reject our null hypothesis and accept our alternative hypothesis which shows that Long working hours / extra commitment demanded by your own business is positively related to low inclination towards self - employment which reflect strong relationship between Long working hours / extra commitment demanded by your own business is positively related to low inclination towards self - employment.

\section{Conclusion}

The research shows that there is not a strong inclination of the business students towards entrepreneurship and self employment. Though, now the state of affairs is seemingly changing but still the general inclination towards self - employment remains very low. The relative rates of self - employment in our country remains very low as compared to other countries. The business students are the most relevant people to the field of business and are taught how to manage and run a business successfully. They are expected to have a high level understanding of the dynamics of business and consequently should be expected to start their own business after completing their business studies. However, there are only a small proportion of current business students which are interested in doing their own business. A vast majority is still planning their career to become employees in organizations as they show low inclination towards entrepreneurship and aspire to have progressive careers in the corporate world. Various factors are responsible for this low trend towards self employment which include lack of innovation and creativity, lack of risk tolerance, lack of resources, unsupportive social environment, lack of support from self - employed people, the lack of promotion of self - employment from teachers, lack of entrepreneurship education, low number of self - employed parents, lack of required human skills and long working hours. All these hypothesized factors are positively related to low inclination towards entrepreneurship.

\section{References}

Alison M. (2000). Entrepreneurship; what triggers it? International Journal of Entrepreneurial Behavior \& Research, Vol, 6 no. 2, 2000, pp. 59-71.

Alison M. A Contextualization of entrepreneurship, , Strathclyde Business School, University of Strathclyde, Glasgow, UK

Tibor R. Machan. Entrepreneurship and ethics, , Leatherby Centre for Entrepreneurship and Business Ethics, School of Business and Economics, Chapman University, Orange, California, USA

Poul D. Promoting entrepreneurship - changing attitudes or behaviour, Denmark.

Harry M. Researching entrepreneurship and education, UCE Business School, Birmingham, UK

Social entrepreneurship: a different model, Roger Spear, Co-ops Research Unit, Open 
University, Milton Keynes, UK

Lars K. Entrepreneurship among business graduates: does a major in entrepreneurship make a difference?

Oystein M. Entrepreneurship education and training: can entrepreneurship be taught? Part I Colette Henry, Dundalk Institute of Technology, Dundalk, Co Louth, Ireland.

James R. Barth, Yago, Zeidman. Barriers to Entrepreneurship in Emerging Domestic Markets: Analysis and Recommendations.

John G. Burch (1986) Journal of Entrepreneurship 2006; 15; 169; Narendra C. Bhandari Kirzner M. (1973). Competition and Entrepreneurship, University of Chicago Press. 